Littel, R. J., Versteeg. G. F. and van Swaaij, W. P. M., 1992, $K$ inetics of COS with primary and secondary amines in aqueous solutions. A.I.Ch.E. J. 38, 244-250.

Sharma, M. M., 1965, Kinetics of reactions of carbonyl sulphide and carbon dioxide with amines and catalysis by Bronsted bases of the hydrolysis of COS. Trans. Faraday Soc. 61, 681-688.

\title{
Author's reply to comments by E. Alper
}

(Received 14 September 1992; accepted 25 September 1992)

\section{Dear Sirs,}

We welcome very much Alper's contribution of additional, and heretofore unpublished, kinetic data for the reaction between $\operatorname{COS}$ and aqueous methyldiethanolamine to enlighten existing discrepancies in open literature on the reaction kinetics of COS with aqueous MDEA. In his Letter to the Editors, Alper shows that his stopped-flow data are in fair agreement with stirred-cell data presented by us at the AIChE 1990 Spring National Meeting, whereas both sets of kinetic data differ very substantially from wetted-sphere data published by Al-Ghawas et al. (1989).

At the AIChE 1990 Meeting we presented preliminary experimental data together with a tentative explanation of the observed phenomena and we stressed the need for further work. Recently we published two papers (I.ittel et al., 1992a, b) in which the reaction of $\operatorname{COS}$ with various aqueous tertiary alkanolamines has been studied in more detail. Two types of experimental techniques were applied for reaction kinetics measurements: the stirred-cell technique in which reaction kinetics are derived from chemically enhanced gas absorption rates and the intensely stirred batch reactor technique in which reaction kinetics are determined under saturated bulk conditions.

The reaction of COS with aqueous MDEA has been studied at concentrations from 100 to $3600 \mathrm{~mol} \mathrm{~m}^{-3}$ and at various temperatures. These experiments provided additional evidence for the validity of the reaction mechanism proposed in our presentation at AIChE 1990 spring Meeting. Furthermore, we showed in these papers that quantitative interpretation of the stirred-cell experiments is severely hampered by the non-validity of a $\mathrm{COS}-\mathrm{N}_{2} \mathrm{O}$ ana-

\footnotetext{
'Present address: Koninklijke/Shell Laboratorium, Amsterdam, PO Box 3003, 1003 AA Amsterdam, The Netherlands.
}

$\operatorname{logy}$, which prevents a reliable estimation of COS solubility in aqueous MDEA solutions above $1500 \mathrm{~mol} \mathrm{~m}^{-3}$. As a result of this observation, the apparent reaction rate constants from preliminary work, as presented by us at AIChE 1990 Spring Meeting and cited by Alper, were found to have been overestimated due to an underestimation of the COS solubility. Finally, using a numerical absorption model we argued that the absorption rates measured by Al-Ghawas et al. (1989) were possibly affected considerably by rapidly reacting contaminants usually present in small amounts in tertiary alkanolamines. In order to avoid this effect in our experiments, we applied experimental conditions which ensured a minimum amine conversion of at least $0.5 \%$.

Department of Chemical Engineering

R. I. I.ITTFI? Twente University of Technology

PO Box 217, 7500 AE Enschede, The Netherlands

\section{REFERENCES}

Al-Ghawas, H. A., Ruiz-Ibanez, G. and Sandall, O. C., 1989, Absorption of carbonyl sulfide in aqueous methyldiethanolamine. Chem. Engng Sci. 44, 631-639.

Littel, R. J., van Swaaij, W. P. M. and Versteeg, G. F., 1990, On the kinetics of carbonylsulphide with tertiary amines in aqueous solution. Paper presented at AIChE Spring National Meeting, Orlando, 19-22 March.

Littel, R. J., Versteeg, G. F. and van Swaaij, W. P. M., 1992a, Kinetic study of COS with tertiary alkanolamine solutions. 1. Experiments in an intensely stirred batch reactor. IEC Res. 31, 1262-1269.

Littel, R. J., Versteeg, G. F. and van Swaaij, W. P. M., 1992b, Kinetic study of $\mathrm{COS}$ with tertiary alkanolamine solutions. 2. Modeling and experiments in a stirred cell reactor. IEC Res. 31, 1269-1274. 